\title{
Effects of Montessori Teaching Method on Writing Ability of Iranian Male and Female EFL Learners
}

\author{
Fatemeh Aghajani \\ English Department, Najafabad Branch, Islamic Azad University, Najafabad, Iran \\ Hadi Salehi (Corresponding author) \\ English Department, Najafabad Branch, Islamic Azad University, Najafabad, Iran \\ Email: hadisalehi1358@yahoo.com
}

Received: 20/08/2020

Accepted: 07/12/2020

Published: 01/01/2021

Volume: 2 Issue: 1

How to cite this paper: Aghajani, F. \& Saheli, H. (2020). Effects of Montessori Teaching Method on Writing Ability of Iranian Male and Female EFL Learners. Journal of Practical Studies in Education, 2(1), 8-15

DOI: https://doi.org/10.46809/jpse.v2i1.17

Copyright (C 2020 by author(s) and Global Talent Academy Ltd. This work is licensed under the Creative Commons Attribution International License (CC BY 4.0).

http://creativecommons.org/licenses/by/4.0/

\section{(c) $(1)$}

\begin{abstract}
This study was an attempt to find out the impact of Montessori teaching method on EFL learners' writing achievement. To fulfill the purpose of the study, out of 150 students, 95 male and female students were selected randomly to participate in this study. All of them were given a pretest to find out their level of proficiency. They had no background knowledge of English and they had not studied English before. They were also divided randomly into two groups namely experimental and control. The experimental group consisted of 23 male and 27 female learners while the control group consisted of 21 male and 24 female learners. Experimental group members were instructed based on Montessori teaching method and their instruction was based on different Montessori materials. The control group members had a routine teaching process. Each group was a mixture of both male and female learners with the age range of 5-6. After 12 sessions, writing posttest was given to both groups to evaluate whether there is any significant difference between these two groups or not. The obtained data were analyzed both descriptively and inferentially. The data were analyzed by statistical tests such as one-way ANCOVA and onesample t-test. The statistical analyses revealed that there was significant statistical differences between two groups mean scores on the writing posttest. Therefore, it can be argued that Montessori teaching method had significant impact on learners' writing skill.
\end{abstract}

Keywords: Teaching Method, Montessori Teaching Method, Writing Ability

\section{Introduction}

EFL learners' success in English writing brings them benefits not only in their English learning but also in their longstanding careers (Tuan, 2010). Furthermore, through writing children learn about themselves, the world, and gain a deeper understanding of academic content (Klein, Acron, \& Baker, 2016; Knipper \& Duggan, 2006; Pennington, 2014). For 
numerous EFL learners, nonetheless, English writing appears to be challenging (Harmer, 1992). In terms of fluency, Nunan (1999) stated that producing a coherent, fluent, extended writing piece is likely the most difficult thing in language since the reader has to comprehend what has been written without asking for clarification or relying on the writer's tone of voice or expression. As writing skill plays a vital role in language learning and development (Steinlen, 2018), Montessori teaching method that presented an innovation in the field of learning is focused in this study. Montessori method is an educational program which is developed spontaneously and intends to give children an opportunity to be able to improve themselves (Montessori, 1997). Maria Montessori believed that "learning and moving are inseparable" and created materials use real actions and objects to translate abstract ideas into concrete form. Materials are designed for the children in a way that they can understand the concepts such as shape, size, color, touching, tasting and the relationship between these concepts (Oktay, 1987). Each specific set of materials within the Montessori curriculum can be adapted to fit the needs of the specific child, using a variety of strategies such as naming games, visual and conceptual matching, and sorting activities (Soundy, 2003). This method has been designed according to the age, level of development and culture (Poyraz ve Dere, 2001). The Montessori curriculum allows the child to explore and channel their creativity through writing, permitting her a variety of educational advantages (Ryan, 2015). Sullivan-Smith (2008) has confirmed that the Montessori program is more effective in developing sensorial skills in preschool children compared with the mainstream method in education. Dr. Montessori did not have a writing curriculum, but instead relied upon the child's desire to learn and write about the subjects that interested him or her mainly within the scientific areas of biology and astronomy (Duffy, 2002). Finally, the teachers can adapt their pedagogic approaches and can mutually design tasks that could motivate and encourage students by giving them liberty of choosing topics of their interest (Pineteh, 2013; Quintero, 2008). In order to facilitate the investigation regarding the effectiveness of Montessori teaching method on the writing ability of Iranian male and female EFL learners, the following three research questions were formulated:

1. Does Montessori teaching method have any significant effect on writing ability of Iranian male EFL learners?

2. Does Montessori teaching method have any significant effect on writing ability of Iranian female EFL learners?

3. What is the attitude of EFL learners toward using Montessori method in enhancing writing ability in EFL context?

\section{Literature Review}

\subsection{History of Montessori Teaching Method}

Maria Montessori was born in the town of Chiaravalle, in the province of Ancona, Italy, 1870. Montessori grew up in a time when teaching was one of the few occupations open to educated women, and her father supported her to follow that path. Montessori, however, showed from an early age that she was a furiously independent and confident woman, and insisted on attending a technical school. In an effort to better the education of Maria and her siblings, her parents decided to move their family to Rome .Montessori became the first woman in Italy to receive the doctoral degree of Medicine in 1896. In 1906, Montessori quit from both her medical practice and her university chair position in order to work with a group of children belonging to working parents in San Lorenzo, Rome. Through her research, Montessori found that children became completely engaged in using specific materials developed by Edward Sequin. So, Montessori carefully observed the children's use of those manipulative materials then designed and developed additional materials to further support children's efforts to find out and develop. Through these observations she learned what children are able to do naturally, unassisted by adults. Montessori's focus became the learner and she developed a child centered approach to education where the focal point was on learning and the learner rather than on instructing and the instructor (Standing, 1957).

Montessori felt that children have an intellectual structure that grows with them. This approach has been necessary in both education and psychology (Dogru, 2015; Murray, 2012). In the education side, the importance of the Montessori approach has evolved from its critical, creative, and sensorial thinking development in children, as well as the development of a child's senses through dealing with sensorial materials. It also has an effect on developing students' language, intellectual, and problem-solving abilities. In addition, it also has effects on children's personality development, confidence, and self-esteem (Barbieru, 2016).

In Montessori teaching method some key programmatic inputs must be noticed. Early childhood stakeholders generally consider these inputs to fall into the structural or process umbrellas. Structural factors are defined as the features of a program that take care of children from harm and support teaching and learning. In contrast, the process characteristics are the educational experiences available to children (Huston, 2015).

2.2. Montessori VS. Traditional Schools

The traditional classrooms were teacher-centered, with learners sitting in rows facing the teacher. The students spent a lot of time repeating and manipulating models provided by the teacher. In this way, some of the students in such classrooms could read texts accurately with beautiful intonation, could stick in mind a lot of words and expressions, but they rarely learned how to make use of this stored knowledge (Meng, 2010).

According to the traditional view, acquiring knowledge demands concentration and discipline, and that the teacher is in charge of creating the discipline needed for learning. On the other hand, Montessori approach suggests that acquiring 
knowledge needs stimulus and a suitable educational environment, and that the teacher's task is to design and foster an environment for learning (Ahmadpour, 2015). Montessori uses her "mental web" metaphor, mentions that a child's mind is like a spider-web passionately hunting moments and phenomena (Hessabi, 2011).

Most traditional schools have one age bracket for every class. On the contrary, Montessori schools include children of different ages in the classroom. Peer teaching and learning does increase student's confidence in practice and also improves learning in the psychomotor and cognitive domains (Secomb, 2008). The younger children are able to see where their education is headed; they see the older children with more challenging materials, and are enthusiastic to work up to the next step. Same age or same skill level grouping can often limit the development of a student (Lillard, 2006).

It is essential for the teacher to lead the child without letting him feel her presence too much, so that she may be always ready to supply the desired help, but may never be the barrier between the child and his experience (Montessori, 1965).

2.3. Effects of Montessori Method on Writing Skill

Even young children can use writing to involve in sociopolitical issues and effect changes in their lives (Kuby, 2013; Vasquez, 2001). "Today in the United States, the aim of education is to make sure that every child becomes literate" (van Kleeck, Schuele, 2010, p. 342). A meta-analysis conducted by Lonigan and Shanahan (2008) describes that the effective literacy-focused preschool and kindergarten interference programs tend to be organized in a manner that corresponds to the holistic/integrated idea. Literacy learning in Montessori is done with the help of several materials. These materials inspire children to talk, name, and describe things, to build words using letters, to read and write object names, and to express their own thoughts in writing, but also to read the written thoughts of others (Philipps, 1999). One of the most famous examples are letters on sandpaper that children can trace with their fingers, thus experiencing them using multiple senses (Bara, Gentaz, Colé, \& Sprenger-Charolles, 2004). A special attention in Montessori curriculum is given to early literacy, with children undergoing the program often learning to write and read before the age of six, following "writing to read" principle (Al et al., 2012, p. 6). This means that children are first thought to write the letters and words (encoding), then to read them (decoding), as Maria Montessori herself observed this approach to be superior

The Montessori curriculum uses a specific set of materials in order to introduce language to the child, both directly and indirectly. When the children enter the Children's House at the age of three, they are immediately put to work-work that is purposeful and enjoyable to the child (Richardson, 1997).

Children in Montessori programs are also regularly participating in various metalinguistic, didactic play activities. This contains explicit phonological awareness exercises. Phonological awareness is a metalinguistic ability related to the general awareness of the sound components of speech. (Rathvon, 2004). A systematic and explicit phonics instruction done at an early age is particularly effective in promoting word recognition, spelling, and reading comprehension (Armbruster, Lehr, \& Osborn, 2010).

\section{Methodology}

\subsection{Participants}

To accomplish the purpose of the study, 95 male and female kindergarten students with the age range of 5-6 participated in this study. The participants who were heterogeneous were randomly selected from available kindergarten students. The instructor took a pretest including some questions related to the alphabet letters. The students had no English background knowledge and they had not studied English before. They were randomly divided into two groups of experimental and control. There were 27 female and 23 male students in the experimental group while the control group consisted of 21 male and 24 female students. The participants in the experimental group were instructed through Montessori teaching method, while those in the control group were only taught through traditional method. Following the completion of the course, both groups received their posttest.

\subsection{Design of the Study}

This study was mixed method and due to the random selection of the initial participants and also dividing them into two groups, the design of the research was experimental research design. The dependent variable of this research was writing ability while independent variable was Montessori teaching method.

\subsection{Instruments and Materials}

The instruments and materials used in this study are explained below:

\subsubsection{Instruments}

\section{Alphabet Pretest}

To achieve the students' proficiency level in English and writing skill, the researcher prepared a pretest for all of the students. This test contains five questions including tracing the letters and telling the sounds, matching the beginning sounds to the pictures, writing the missing letters, circling the appropriate sound and finally making the puzzle and writing the letter. The time needed for answering the test was 40 minutes.

\section{Alphabet Posttest}

To achieve the purpose of the study, the researcher gave a test of alphabet letters which were taught to both experimental and control group. This test contains seven questions in which the learners were supposed to trace the alphabet letters on sand papers and tell the sounds, write the alphabet letters, write CVC words based on the picture, put the objects in appropriate 
boxes, fish out the letters and finally make the puzzle of the picture and write the noun by moveable alphabets. The time needed for answering the test was approximately 30 minutes.

Questionnaire

To unveil the EG learners' attitudes towards the treatment they received, they were interviewed using some of the questions based on the characteristics of Montessori Teaching Method. Then, their responses were converted to a 10-item Likert scale (with options ranging from strongly disagree to strongly agree) questionnaire.

\subsubsection{Materials}

Coursebook

The main textbook that was used at this level was "Hip Hip Hooray starter" by Eisele, Hanlon that was used as their course book. The mentioned textbook contains of different parts with emphasis on all four skills (listening, reading, writing and speaking) and also sub-skills (vocabulary and grammar). It also has a work book and a CD that was played for parts such as stories, vocabulary and the alphabet sounds.

Sand Tray and Sandpaper Letters

The Sandpaper letters are one of Maria Montessori's most brilliant materials. By working with the Sandpaper letters, children learn how the sounds they hear are written. In Sandpaper letters, the vowels are in blue and the consonants are in red. Montessori emphasized that writing comes first, then reading. Later, by blending these sounds together, children begin to read phonetic words without laborious effort.

\section{Moveable Alphabet}

In brief, a moveable alphabet is a tool used in a Montessori learning environment to teach reading, spelling, and writing. It is a wooden box containing 26 wooden letters. Vowels are in blue and consonants are in red. Once a child has a firm understanding of the Sandpaper letters, they will move on to the moveable alphabet to write words.

Phonetic Object Boxes

As a child grows, s/he soon learns that the written word is one more way to communicate with the world. That is where the Phonetic Object Box comes in. It is a step towards reading fluently, and incorporates writing practice as well. The children are accustomed to working with second sounds and may need some time to fuse the sounds together to make a word with meaning.

\subsection{Procedure}

In order to achieve the purpose of the research, the following procedure was carried out. The researcher first selected the kindergarten EFL students randomly. Ninety five students were needed for instructing the course. There were 44 boys and 51 girls participating in the study. Their classroom was supposed to be a multi-age classroom which is fundamental to the Montessori method. The researcher divided them into two groups with different age range, gender, and characteristics. The first group was experimental that the Montessori teaching method was used throughout the course and the second group was control that they were going to be taught based on the traditional method. The duration of the treatment was 12 sessions in which one session was for making students familiar with the Montessori teaching method and the last session devoted to administering the posttest. Each session lasted for 90 minutes.

\subsection{Data Analysis}

The data analysis in this study was comprised of two series of calculations, descriptive statistics and inferential statistics. The collected data were analyzed in relation to the research questions of the study and the data analysis was done by statistical tests such as one-way ANCOVA and one-sample $t$ test. The one-way ANCOVA is used to test the main effects of categorical independent variable on a continuous dependent variable while controlling for the effect of other continuous variables which co-vary with the dependent. For inferential statistics, sample $t$ test was used in order to investigate whether Montessori teaching method had any statistically significant impact on EFL learners writing achievement.

\section{Results}

As the first research question of the study was concerned with investigating any possible effects of Montessori teaching method on the writing ability of Iranian male EFL learners, the researcher had to compare the posttest scores of the EG and CG learners.

\section{Table 1: Descriptive Statistics for Comparing the Posttest Scores of the EG and CG Male Learners}

\begin{tabular}{llll}
\hline Groups & Mean & Std. Deviation & $N$ \\
\hline EG & 17.91 & 1.44 & 23 \\
\hline CG & 15.80 & 1.83 & 21 \\
\hline Total & 16.90 & 1.93 & 44 \\
\hline
\end{tabular}

In Table 1, it could be found that the posttest mean score of the EG male learners $(M=17.91)$ was larger than the posttest mean score of the CG male learners $(M=15.80)$. To find out whether this difference was a statistically significant one or not, the researcher had to look down the Sig. column and in front of the Groups row in Table 2: 
Table 2: Results of One-Way ANCOVA for Comparing the Posttest Scores of the EG and CG Male Learners

\begin{tabular}{lllllll}
\hline Source & $\begin{array}{l}\text { Type III Sum of } d f \\
\text { Squares }\end{array}$ & Mean Square & $F$ & Sig. & $\begin{array}{l}\text { Partial } \\
\text { Squared }\end{array}$ & Eta \\
\hline Corrected Model & 49.85 & 2 & 24.92 & 9.14 & .00 & .30 \\
\hline Intercept & 4841.78 & 1 & 4841.78 & 1775.85 & .00 & .97 \\
\hline Pretest & 1.28 & 1 & 1.28 & .46 & .49 & .01 \\
\hline Groups & 49.30 & 1 & 49.30 & 18.08 & .00 & .30 \\
\hline Error & 111.78 & 41 & 2.72 & & & \\
\hline Total & 12742.00 & 44 & & & & \\
\hline Corrected Total & 161.63 & 43 & & & & \\
\hline
\end{tabular}

The $p$ value here was smaller than the alpha level of significance $(.00<.05)$, which indicates that the difference between the male learners in the two groups of EG $(M=17.91)$ and $\mathrm{CG}(M=15.80)$ on the posttest was statistically significant. This means that using Montessori Teaching Method was significantly more effective than using traditional instruction in improving the EFL learners' writing.

The second research question of the study was formulated to find out whether using Montessori Teaching Method could have any significant effects on female EFL learners' writing in L2 or not. Thus, the researcher needs to compare the posttest scores of two groups.

Table 3: Descriptive Statistics for Comparing the Posttest Scores of the EG and CG Female Learners

\begin{tabular}{llll}
\hline Groups & Mean & Std. Deviation & $N$ \\
\hline EG & 17.55 & 1.31 & 27 \\
\hline CG & 15.79 & 1.74 & 24 \\
\hline Total & 16.72 & 1.75 & 51 \\
\hline
\end{tabular}

It could be seen that the posttest mean score of the female EG learners $(M=17.55)$ was higher than the posttest mean score of the female CG learners $(M=15.79)$. To figure out whether this difference between the posttest scores of the female learners in the EG and CG was a statistically significant one or not, the researcher had to examine the $p$ value under the Sig. column and in front of the Groups row in Table 4.

Table 4: Results of One-Way ANCOVA for Comparing the Posttest Scores of the EG and CG Female Learners

\begin{tabular}{lllllll}
\hline Source & $\begin{array}{l}\text { Type III Sum of } d f \\
\text { Squares }\end{array}$ & Mean Square & $F$ & Sig. & $\begin{array}{l}\text { Partial } \\
\text { Squared }\end{array}$ & Eta \\
\hline Corrected Model & 43.15 & 2 & 21.57 & 9.33 & .00 & .28 \\
\hline Intercept & 3668.69 & 1 & 3668.69 & 1586.42 & .00 & .97 \\
\hline Pretest & 3.62 & 1 & 3.62 & 1.56 & .21 & .03 \\
\hline Groups & 43.11 & 1 & 43.11 & 18.64 & .00 & .28 \\
\hline Error & 111.00 & 48 & 2.31 & & & \\
\hline Total & 14421.00 & 51 & & & & \\
\hline Corrected Total & 154.15 & 50 & & & & \\
\hline
\end{tabular}

In Table 4, the $p$ value in the row labeled Groups was found to be lower than the alpha level of significance $(.00<.05)$, indicating that the difference between the female learners in the two groups of EG $(M=17.55)$ and CG $(M=15.79)$ on the posttest was a statistically significant one. It could thus be inferred that using Montessori Teaching Method was significantly more effective than traditional instruction in improving the EFL learners' writing

Finally, to unveil the EG learners' attitudes towards the treatment they received, they were interviewed using some of the questions based on the characteristics of Montessori Teaching Method. Then, their responses were converted to a 10-item Likert scale (with options ranging from strongly disagree to strongly agree) questionnaire.

Table 5: Results of the EG Learners' Attitudes towards Montessori Teaching Method

\begin{tabular}{|c|c|c|c|c|c|c|c|}
\hline No & Statements & $\begin{array}{l}\text { Strongly } \\
\text { agree }\end{array}$ & Agree & $\begin{array}{l}\text { No } \\
\text { opinion }\end{array}$ & Disagree & $\begin{array}{l}\text { Strongly } \\
\text { disagree }\end{array}$ & Mean \\
\hline 1 & $\begin{array}{l}\text { It is good to learn from other learners who are } \\
\text { older or younger than me. }\end{array}$ & 15 & 23 & 12 & 0 & 0 & 4.06 \\
\hline
\end{tabular}




\begin{tabular}{|c|c|c|c|c|c|c|c|}
\hline 2 & I can learn to be responsible for my learning. & 16 & 20 & 14 & 0 & 0 & 4.04 \\
\hline 3 & $\begin{array}{l}\text { The way I learned English helped me become } \\
\text { independent. }\end{array}$ & 22 & 25 & 3 & 0 & 0 & 4.38 \\
\hline 4 & $\begin{array}{l}\text { I liked the activities I did in class to learn } \\
\text { English. }\end{array}$ & 13 & 28 & 9 & 0 & 0 & 4.08 \\
\hline 5 & I liked what my teacher did in class. & 8 & 35 & 7 & 0 & 0 & 4.02 \\
\hline 6 & My parents also helped me learn English. & 15 & 29 & 6 & 0 & 0 & 4.18 \\
\hline 7 & $\begin{array}{l}\text { The teacher and other students helped and } \\
\text { supported me. }\end{array}$ & 11 & 31 & 8 & 0 & 0 & 4.06 \\
\hline 8 & I think I learned a lot in my class. & 21 & 23 & 6 & 0 & 0 & 4.30 \\
\hline 9 & I learned to have self-discipline in my class. & 13 & 32 & 5 & 0 & 0 & 4.16 \\
\hline 10 & I want to have similar classes in the future. & 26 & 22 & 2 & 0 & 0 & 4.48 \\
\hline
\end{tabular}

The EG learners had positive attitudes towards all those 10 items. The total mean score obtained from the questionnaire items, as is shown in Table 6, is 4.17. To see if this degree of having positive attitudes is statistically large/significant or not, the $p$ value in the one-sample $t$ test table should be examined:

Table 6: One-Sample t Test Results for the EG Learners' Attitudes

Test Value $=3$

\begin{tabular}{|c|c|c|c|c|c|c|}
\hline & & & & & $\begin{array}{l}95 \% \\
\text { Interval } \\
\text { Difference }\end{array}$ & $\begin{array}{l}\text { Confidence } \\
\text { of the }\end{array}$ \\
\hline$t$ & $d f$ & $\begin{array}{l}\text { Sig. } \\
\text { (2-tailed) }\end{array}$ & $\begin{array}{l}\text { Overall } \\
\text { Questionnaire } \\
\text { Mean }\end{array}$ & $\begin{array}{l}\text { Mean } \\
\text { Difference }\end{array}$ & Lower & Upper \\
\hline 23.33 & 9 & .00 & 4.17 & 1.17 & 1.06 & 1.29 \\
\hline
\end{tabular}

Because the $p$ value in this table is lower than the significance level $(.00<.05)$, it could be understood that the EG learners held significantly positive attitudes towards Montessori Teaching Method for the purpose of improving their L2 writing.

\section{Discussion and Conclusion}

Writing ability has always been considered as a challenge for many L2 students. For some students, it is true that writing is the difficult skill because in writing the students must generate and organize their ideas to solve the difficulties in writing. The present study attempts to investigate the impact of Montessori teaching method on male and female EFL learners' writing achievement. Based on the results, it can be argued that the null hypothesis was rejected, favoring the experimental group. That is, Montessori teaching method had significant impact on learners' writing skill.

Dr. Maria Montessori created the Montessori curriculum based on the child's needs. Maria Montessori observed that the importance of introducing language, specifically reading and writing, to a young child is essential in order to utilize the sensitive period of the child (Lillard, 2008). Richardson (1997) illustrated the systematic progression to support learning with the materials, and how the materials introduce the child to the whole concept before breaking it down into parts. The results of this study is consistent with that of Ryan's (2015) study about importance of writing before reading by the use of Montessori method on both male and female kindergarten learners and the results for improvement in reading and writing for the Montessori class as a whole was quite positive and it significantly had impact on students' writing ability.

The present study focused on the impact of Montessori teaching method on male and female EFL learners' writing achievement. The subsequent recommendations are discussed here hoping that they would draw the attention of researchers in continuity of this study: 
- Only learners with the age range of 5-6 participated in this study, it may be interesting to see whether other age range is also a factor.

- This study focused on writing skill; another study can be carried out to investigate the impact of Montessori teaching method on EFL learners' another skill.

- The researcher used some of the available materials related to the Montessori, another study could be conducted including other materials to investigate the effect of other materials.

\section{References}

Ahmadpour.N. (2015). The impact of Montessori teaching method on IQ levels of 5-year old children. Procedia-Social and Behavioral Sciences, 205, 122-127.

Al, S. S. (2012). A different perspective on education: Montessori and Montessori school architecture. Procedia-Social and Behavioral Sciences, 46, 1866-1871.

Armbruster, B. B. (2010). Put reading first: The research building blocks for teaching children to read (3rd ed.). National Institute for Literacy. Retrieved from Retrieved from http://goo.gl/ON1msr

Bara, F. G.-C. (2004). The visuo-haptic and haptic exploration of letters increases the kindergarten-children's understanding of the alphabetic principle. Cognitive development. 19(3), 433-449.

Barbieru, I. T. (2016). The Role of the Educator in a Montessori Classroom. Revista Romaneasca pentru Educatie Multidimensionala. 8(1), 107-123. doi: http://dx.doi.org/10.18662/rrem/2016.0801.07.

Dogru, S. (2015). Efficacy of Montessori education in attention gathering skill of children. Academic Journals, 10(6), 733738.

Duffy, M. \&. (2002). Children of the universe: Cosmic education in the Montessori elementary classroom. Hollidaysburg, PA: Parent Child Press. .

Hessabi, M. (2011). Montessori method and its impact on self-esteem, independence and social skills in children. Development of Preschool Education, 2(3), 13. [Persian].

Huston, A. C. (2015). How can public policy improve quality of early care and education? International Journal of Child Care and Education Policy, 2(1), 1-14. .

Klein, P. A. (2016). Writing to learn. In C. MacArthur, S. Graham, \& J. Fitzgerald (Eds.) Handbook of Writing Research (pp. 243-256). New York, NY: Guilford Press. .

Knipper, K. J. (2006). Writing to learn across the curriculum: Tools for comprehension in content area classes. The Reading Teacher, 59(5), 462-470.

Kuby, C. (2013). Critical literacy in the early childhood classroom: Unpacking histories, unlearning privilege. New York, NY: Teachers College Press. .

Lillard, A. S.-Q. (2006). The early years: Evaluating Montessori education. Science, 313, 1893-94.

Lonigan, C. J. (2008). Developing early literacy: Report of the National Early Literacy Panel: A scientific synthesis of early literacy development and implications for intervention. Washington, DC: National Institute for Literacy.

Meng, J. (2010). Cooperative learning method in the practice of English reading and speaking. Journal of Language Teaching and Research, 1(5), 701-703.

Montessori, M. (1965). Dr. Montessori's own handbook: A short guide to her ideas and materials. New York, NY: Schocken books Inc.

Montessori, M. (1997). Child Education Montessori Method. Translator; Güler Yücel. Özgür Publication, 5. Issue, Istanbul.

Murray, A. (2012). Public knowledge of Montessori education. Montessori Life, 24(1), 18-21.

Nunan, D. (1999). Second language teaching \& learning. Boston, MA: Heinle \& Heinle.

Oktay, A. (1987). A contemporary approach to preschool education: Montessori Method. The Seminar of Preschool Education.

Pennington, M. (2014). Every child a writer. Writing \& Pedagogy, 6(3), 443-455.

Philips, S. (1999). Montessori priprema za život: odgoj neovisnosti i odgovornosti [Montessori preparation for life: Education of independence and responsibility]. Jastrebarsko: Naklada Slap.

Pineteh, E. A. (2013). The academic writing challenges of undergraduate students: A South African case study. International Journal of Higher Education, 3(1), 12.

Poyraz, H. D. (2001). The principles and the Methods of preschool education. An Publication, Istanbul.

Quintero, L. M. (2008). A way to foster EFL writing. Colombian Applied Linguistics Journal, 10 (1), 7-49.

Rathvon, N. (2004). Early reading assessment: A practitioner's handbook. New York, NY: The Guilford Press.

Richardson, S. O. (1997). The Montessori Preschool: Preparation for Writing and Reading. Annals of Dyslexia, 47, $241-256$.

Ryan, T. (2015). The Importance of writing before reading; How Montessori materials and curriculum support this learning process. Retrieved from https://minds.wisconsin.edu/handle/1793/74007

Secomb, J. (2008). A systematic review of peer teaching and learning in clinical education. Journal of Clinical Nursing, 703. Retrieved from http://dx.doi.org/10.1111/j.1365-2702.2007.01954.x. 
Soundy, S. C. (2003). Exemplary Montessori practice for all Literacy teachers. Early Childhood Education Journal, 31(2), 127-31.

Standing, E. M. (1957). Montessori: Her Life and Work. The New American Library, New York. US.

Steinlen, A. K. (2018). The development of German English writing skills in a bilingual primary school in Germany. Journal of Second Language Writing, 39, 42-52.

Sullivan-Smith, M. (2008). Montessori and children with autism sensory skill fullness. NAMTA Journal, 33 (2), 68-75.

Tuan, L. P. (2010). Enhancing EFL Learners' Writing Skill via Journal Writing. National University of Ho Chi Minh City, $3(3)$.

Van Kleeck, A., \& Schuele, C. M. (2010). Historical Perspectives on Literacy in Early Childhood. American Journal of Speech-Language Pathology, 19 (4), 341-355.

Vasquez, V. (2001). Constructing a critical curriculum with young children. In B. Comber \& A. Simpson (Eds.) Negotiating critical literacies in classrooms (pp. 55-66). Mahwah, NJ: Erlbaum. 